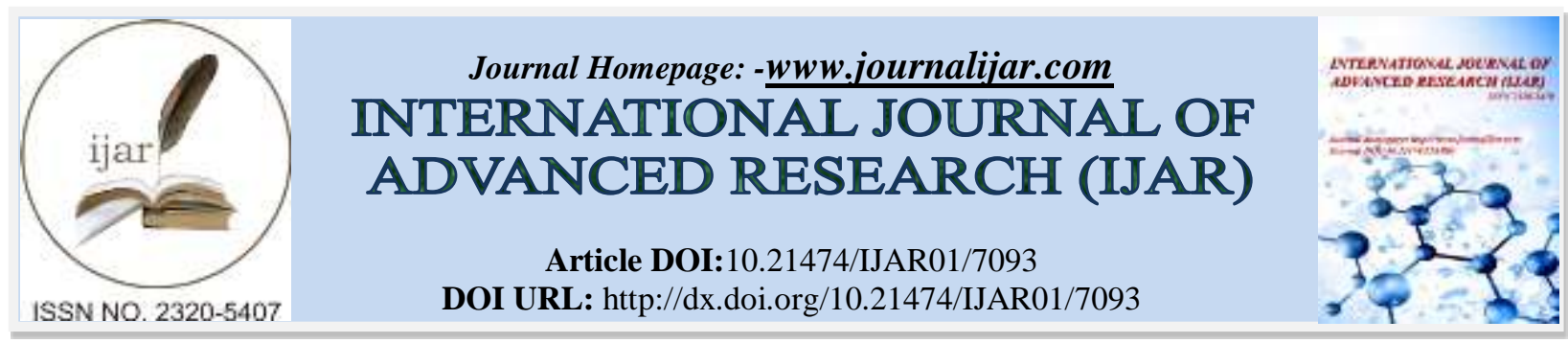

RESEARCH ARTICLE

\title{
QUALITY CHARACTERISTICS OF FUNCTIONAL SEASONED MEAT SUPPLEMENTED WITH SILKWORM POWDER AND SILKWORM CORDYCEPS DURING STORAGE.
}

\author{
Il-Suk Kim, Tae Wan Kim and Sam Woong Kim. \\ Swine Science and Technology Center, Gyeongnam National University of Science and Technology, Gyeongnam, \\ Jinju 52725, South Korea.
}

\section{Manuscript Info}

Manuscript History

Received: 13 March 2018

Final Accepted: 15 April 2018

Published: May 2018

Keywords:-

Functional Meat Products, Seasoning

Meat, Silkworm Cordyceps, Silkworm

Powder, Stability, Storage.

\begin{abstract}
This study was done to evaluate the effects of silkworm powder or silkworm cordyceps on quality of seasoned meat during storage. The $\mathrm{pH}$ was significantly lower in silkworm cordyceps group than those of the other groups $(\mathrm{p}<0.05)$, whereas saccharinity showed the opposite phenomenon. Shear forces of the treated groups were significantly higher than that of the control group $(\mathrm{p}<0.05)$. Lightness $\left(\mathrm{L}^{*}\right)$, redness $\left(a^{*}\right)$ and yellowness $\left(b^{*}\right)$ were significantly higher in silkworm powder than other treatments $(\mathrm{p}<0.05)$. TBARS, VBN and total bacterial counts in silkworm cordyceps group were significantly lower $(p<0.05)$ than those of the other groups $(p<0.05)$. As a result of sensory evaluation, the treated groups during storage were lower values in the aroma and tenderness than those in the control, but the overall acceptances were very good at 8 days. According to the results of this study, since silkworm powder or silkworm cordyceps can improve the quality of the seasoned meat during storage, it is suggested that the materials can be applied as food materials for improvement of storage stability.
\end{abstract}

Copy Right, IJAR, 2018,. All rights reserved.

\section{Introduction:-}

The seasoned meat to be mainly consumed in Korea include seasoned ribs, bulgogi, and fried meat. These products are made to spices together with garlic, onion, green pepper and pepper powder in a soy sauce or a kochujang, and the spices are mixed together with meat, and the products are generally sold after about 2-3 days of aging process. The seasoning products remove bad meat smell and enhance the inherent flavor of the seasoning as well as has a good effect on digestion rate according to ingestion (Moon et al., 1991).

The edible meat products to prolong shelf life and prevent quality deterioration have been used by inexpensive synthetic antioxidants such as butylated hydroxytoluene (BHT), butylated hydroxyanisol (BHA), and propyl gallate (MaCarthy, et al., 2001; Minussi, et al., 2003). In addition, sorbic acid is used as a synthetic preservative, and nitrates and nitrites are used as coloring agents (Youn et al., 2007; Montesinos-Herroro, et al., 2009). However, as these synthetic food additives are suspected to be carcinogenic, consumers are eager to reduce the use of synthetic food additives in the meat industry (Namiki, 1990). Therefore, the use of natural food additives for the food industry is advantageous because it is a natural product that does not require multiple safety tests before use (Yang, et al., 2015). 
Since unfavorable pork regions are cheap and solve the problems of adult diseases and obesity to a certain extent due to low fat and high protein content, consumer promotion campaigns for these pork regions are also taking place recently through media. However, there is no concrete method of consumption method. However, some researchers have suggested the development of a variety of seasonings using Korean traditional spices. The spices used in the previous study have the effects of improving palatability, tenderness, texture, and water holding capacity, but of removing odor (Jeon, et al., 2002; Oh, 1986). As the other examples, unfavorable pork regions have been studied on the quality change and shelf life of soy sauce- and kochujang-seasoned porks during refrigeration, and the changes in taste components during fermentation of traditional soy sauce (Choi and Lee, 2002; Hah, et al., 2005).

In this study, we assessed effect of silkworm powder and silkworm cordyceps on the storage stability of seasoned meat. As a result, these additives are able to improve storage stability of the seasoned meats and to apply as a food material.

\section{Materials and Methods:- \\ Preparation of functional seasoned meat:-}

After removing excess fat and connective tissues, a hind leg of Berkshire was cut into $70 \times 10 \times 10 \mathrm{~mm}$ and mixed thoroughly with the ratio shown in Table 1 . The samples were set at $0.2 \%$ of silkworm powder (SP $0.2 \%$ ) and $0.4 \%$ of silkworm cordyceps (SC 0.4\%) and non-additive (CTL), respectively. The mixed product was placed in a plastic container and covered with a lid. The packaged samples were stored for 8 days in a refrigerator at $5 \pm 1{ }^{\circ} \mathrm{C}$ for quality measurement.

\section{pH, salinity and saccharinity:-}

An aliquot of the sample $(10 \mathrm{~g})$ was mixed with $90 \mathrm{~mL}$ of distilled water, homogenized in a homogenizer (T25B, IKA Sdn. Bhd., Malaysia) for 10 seconds at $13,500 \mathrm{rpm}$ and then measured with a $\mathrm{pH}$ meter (8603, Metrohm, Swiss). An aliquot of the sample ( $3 \mathrm{~g}$ ) was diluted by $27 \mathrm{ml}$ of distilled water, and the salinity and saccharinity were measured with a salinity meter (TM-30D, Kakemura, Japan) and a sugar meter (PR-101, ATAGO, Japan), respectively.

\section{TBARS and VBN:-}

TBARS was measured by the method of Buege and Aust (1978). Briefly, the reaction mixture was prepared and homogenized by $5 \mathrm{~g}$ of the sample, $50 \mu \mathrm{l}$ of butylated hydroxyanisole (BHA) and $15 \mathrm{ml}$ of distilled water. An aliquot $(1 \mathrm{ml})$ of the homogenate was placed in a test tube, and added and homogenized by $2 \mathrm{ml}$ of thiobarbituric acid (TBA)/trichloroacetic acid (TCA). The treated solution was treated in a water bath at $90^{\circ} \mathrm{C}$ for $15 \mathrm{~min}$, cooled, and then centrifuged at 3,000 rpm for $10 \mathrm{~min}$. The upper layer of the centrifuged sample was collected and absorbance was measured at $531 \mathrm{~nm}$. TBARS was calculated by the following equation.

$$
\text { TBARS }=\text { Absorbance value at } 531 \mathrm{~nm} \times 5.88
$$

VBN was measured using the method of Pearson (1968). Briefly, after homogenizing the mixture of the chopped meat $10 \mathrm{~g}$ and $90 \mathrm{ml}$ distilled water, the homogenized solution was filtered with whatman No. $1,1 \mathrm{ml}$ of the filtrate was added into out chamber of the conway unit, whereas $1 \mathrm{ml}$ of $0.01 \mathrm{~N}$ boric acid solution and an indicator $(0.066 \%$ methyl red $+0.066 \%$ bromocresol green) were added into inner chamber of the conway unit. Glycerine was applied to the adhesion site of the conway unit with the lid, $1 \mathrm{ml}$ of $50 \% \mathrm{~K}_{2} \mathrm{CO}_{3}$ was injected into the outer chamber and then immediately sealed. The container was then stirred horizontally and incubated at $37^{\circ} \mathrm{C}$ for 120 minutes. After incubation, the boric acid solution of the inner chamber was measured with $0.02 \mathrm{~N} \mathrm{H}_{2} \mathrm{SO}_{4}$. VBN was calculated by the following equation.

$$
V B N(m g \%)=(a-b) \times f \times 0.02 \times 14.007 \times / S \times 100 \times 100
$$

a; sample ml, b; blank ml, S; sample wt, f; $0.02 \mathrm{~N} \mathrm{H}_{2} \mathrm{SO}_{4}$ factor

\section{Shear force and meat color:-}

Shear force was examined by a knife-type plunger with a $5 \mathrm{~mm}$ diameter by laying down a cylindrical fresh meat $(\varnothing 1.8 \times 2.0 \mathrm{~cm})$ horizontally using Instron 3343 (US / MX50, A \& \& D Co., USA) as a shearing cutting test.

Meat color was measured 5 times repeatedly by Chromameter (Minolta Co. CR 400, Japan) in the same manner. Deep meat color was analyzed by cutting the meat at 90 degrees and then measured the surface in the same manner 
as surface meat color to determine the $\mathrm{L}^{*}$ value indicating the lightness, the $\mathrm{a}^{*}$ value indicating the redness and the $\mathrm{b}^{*}$ value indicating the yellowness. The standard color was standardized using a standard color plate with an $\mathrm{L}^{*}$ value of $89.2, a^{*}$ value of 0.921 , and $a b^{*}$ value of 0.783 . Sausages were allowed to stand at room temperature for 5 minutes, cut into $0.5 \mathrm{~cm}$ thick and then measured for color.

Total bacterial counts and sensory evaluation:-

Water activity was measured at room temperature with a water activity meter $\left(\mathrm{O} 2 \& \mathrm{CO}_{2}\right.$ analyzer LKM200A, Lokas, Korea). In order to determine the total number of bacteria, $10 \mathrm{~g}$ of sample was mixed with $90 \mathrm{ml}$ of $1 \%$ peptone, homogenized with a bagmixer, and then $1 \mathrm{ml}$ was diluted with $9 \mathrm{ml}$ of peptone water. The diluted solution was plated on a plate counter agar (Difco), and the number of colonies were counted after incubation at $32^{\circ} \mathrm{C}$ for 2 days.

Sensory evaluation was done by 10 sensory test workers and 9 point scale was used for each test. Sausages were analyzed for color, flavor, odor and overall acceptability after heating. 1 point marks extremely bad or slight, and 9 point marks extremely good or much.

\section{Statistical analysis:-}

The results obtained from the above tests were analyzed by the GLM (General Linear Model) method of SAS (1999) and Duncan's Multiple Range Test was used for the comparison of the treatment averages.

Table 1;-Formular of functional seasoned meat

\begin{tabular}{|l|c|c|c|}
\hline \multirow{2}{*}{\multicolumn{1}{|c|}{ Raw materials }} & \multicolumn{3}{c|}{ Treatment $^{\mathbf{1}}$} \\
\cline { 2 - 4 } & CTL 0\% & SP 0.2\% & SC 0.4\% \\
\hline hind leg of Berkshire & 68.658 & 68.658 & 68.658 \\
\hline Sesame oil & 0.446 & 0.446 & 0.446 \\
\hline Green onion & 4.119 & 4.119 & 4.119 \\
\hline Onion & 6.866 & 6.666 & 6.666 \\
\hline Fork seasoning sauce ${ }^{2)}$ & 19.911 & 19.911 & 19.911 \\
\hline Silkworm powder & - & 0.200 & - \\
\hline Silkworm cordyceps & - & - & 0.400 \\
\hline Total & 100.000 & 100.000 & 100.00 \\
\hline
\end{tabular}

CTL (Control); non treated, SP 0.2\%; added with $0.2 \%$ silkworm powder, SC 0.4\%; added with $0.4 \%$ silkworm cordyceps.

Fork seasoning sauce mixing ratio (chopped garlic 5.821, chopped onion 14.552, Choice Mix - F2 18.510, Kochujang 37.835, water 20.373, Chongha 2.910, total 100\%).

Table 2;-Changes in $\mathrm{pH}$ during cold storage

\begin{tabular}{|l|c|c|c|c|}
\hline \multirow{2}{*}{ Treatments $^{1)}$} & \multicolumn{4}{|c|}{ Storage days } \\
\cline { 2 - 5 } & $\mathbf{0}$ & $\mathbf{2}$ & $\mathbf{4}$ & $\mathbf{8}$ \\
\hline CTL 0\% & $5.87 \pm 0.03^{\mathrm{Ba}}$ & $5.79 \pm 0.02^{\mathrm{Bb}}$ & $6.05 \pm 0.06^{\mathrm{Aa}}$ & $5.89 \pm 0.09^{\mathrm{Ba}}$ \\
\hline SP 0.2\% & $5.83 \pm 0.02^{\mathrm{Ba}}$ & $5.85 \pm 0.01^{\mathrm{Ba}}$ & $5.88 \pm 0.02^{\mathrm{ABb}}$ & $5.92 \pm 0.05^{\mathrm{Aa}}$ \\
\hline SC 0.4\% & $5.74 \pm 0.01^{\mathrm{Bb}}$ & $5.73 \pm 0.02^{\mathrm{Bc}}$ & $5.80 \pm 0.02^{\mathrm{Ac}}$ & $5.73 \pm 0.02^{\mathrm{Bb}}$ \\
\hline
\end{tabular}

${ }^{1)}$ Treatments are the same as in Table 2.

${ }^{a, b, c}$ Means \pm SD with different superscripts in the same column significantly differ at $\mathrm{p}<0.05$.

${ }^{\mathrm{A}, \mathrm{B}}$ Means \pm SD with different superscripts in the same row significantly differ at $\mathrm{p}<0.05$.

Table 3:-Changes in salinity and saccharinity during cold storage

\begin{tabular}{|c|c|c|c|c|c|}
\hline \multirow{2}{*}{\multicolumn{2}{|c|}{ Treatments $^{1)}$}} & \multicolumn{4}{|c|}{ Storage days } \\
\hline & & \multirow{2}{*}{$\begin{array}{c}\mathbf{0} \\
0.6 \pm 0.00^{\mathrm{B}}\end{array}$} & \multirow{2}{*}{$\frac{\mathbf{2}}{0.6 \pm 0.00^{\mathrm{Ba}}}$} & \multirow{2}{*}{$\frac{\mathbf{4}}{0.7 \pm 0.01^{\text {Aa }}}$} & \multirow{2}{*}{$\begin{array}{c}\mathbf{8} \\
0.7 \pm 0.00^{\mathrm{Aa}}\end{array}$} \\
\hline Salinity & CTL 0\% & & & & \\
\hline$(\%)$ & SP 0.2\% & $0.6 \pm 0.00$ & $0.6 \pm 0.01^{\mathrm{a}}$ & $0.6 \pm 0.00^{\mathrm{b}}$ & $0.6 \pm 0.00^{\mathrm{b}}$ \\
\hline & $\mathrm{SC} 0.4 \%$ & $0.6 \pm 0.00^{A}$ & $0.5 \pm 0.00^{\mathrm{Bb}}$ & $0.6 \pm 0.00^{\mathrm{Ab}}$ & $0.6 \pm 0.00^{\mathrm{Ab}}$ \\
\hline \multirow{3}{*}{$\begin{array}{l}\text { Saccarinity } \\
(\%)\end{array}$} & CTL 0\% & $13.00 \pm 0.17^{\mathrm{Cc}}$ & $12.70 \pm 0.06^{\mathrm{Dc}}$ & $15.70 \pm 0.12^{\mathrm{Ba}}$ & $17.30 \pm 0.06^{\mathrm{Ab}}$ \\
\hline & SP 0.2\% & $13.30 \pm 0.12^{\mathrm{Cb}}$ & $13.00 \pm 0.00^{\mathrm{Db}}$ & $14.00 \pm 0.00^{\mathrm{Bc}}$ & $15.70 \pm 0.06^{\mathrm{Ac}}$ \\
\hline & SC 0.4\% & $14.00 \pm 0.00^{\mathrm{Ca}}$ & $14.00 \pm 0.10^{\mathrm{Ca}}$ & $14.70 \pm 0.06^{\mathrm{Bb}}$ & $18.00 \pm 0.00^{\mathrm{Aa}}$ \\
\hline
\end{tabular}


Treatments are the same as in Table 2.

${ }_{a, b, c}$ Means $\pm S D$ with different superscripts in the same column significantly differ at $\mathrm{p}<0.05$.

$\mathrm{A}, \mathrm{B}, \mathrm{C}, \mathrm{D}$ Means $\pm \mathrm{SD}$ with different superscripts in the same row significantly differ at $\mathrm{p}<0.05$.

Table 4:-Changes in shear force $\left(\mathrm{kg} / \mathrm{cm}^{2}\right)$ during cold storage

\begin{tabular}{|l|c|c|c|c|}
\hline \multirow{2}{*}{ Treatments $^{1)}$} & \multicolumn{4}{|c|}{ Storage days } \\
\cline { 2 - 5 } & 0 & 2 & 4 & 8 \\
\hline CTL 0\% & $7.80 \pm 1.32^{\mathrm{Ab}}$ & $6.51 \pm 0.38^{\mathrm{ABb}}$ & $5.10 \pm 0.79^{\mathrm{BCb}}$ & $4.41 \pm 0.58^{\mathrm{Cb}}$ \\
\hline SP 0.2\% & $11.02 \pm 1.79^{\mathrm{Aa}}$ & $11.09 \pm 0.78^{\mathrm{Aa}}$ & $9.08 \pm 0.91^{\mathrm{ABa}}$ & $8.25 \pm 0.89^{\mathrm{Ba}}$ \\
\hline SC 0.4\% & $12.33 \pm 1.46^{\mathrm{Aa}}$ & $10.59 \pm 1.05^{\mathrm{ABa}}$ & $7.90 \pm 0.47^{\mathrm{BCa}}$ & $7.53 \pm 2.35^{\mathrm{Ca}}$ \\
\hline
\end{tabular}

${ }^{1)}$ Treatments are the same as in Table 2.

${ }^{\mathrm{a}, \mathrm{b}}$ Means \pm SD with different superscripts in the same column significantly differ at $\mathrm{p}<0.05$.

${ }^{\mathrm{A}, \mathrm{B},}$ Means $\pm \mathrm{SD}$ with different superscripts in the same row significantly differ at $\mathrm{p}<0.05$.

Table 5:-Changes in meat color during cold storage

\begin{tabular}{|c|c|c|c|c|c|}
\hline \multirow{2}{*}{\multicolumn{2}{|c|}{ Treatments $^{1)}$}} & \multicolumn{4}{|c|}{$\begin{array}{l}\text { Storage days } \\
\end{array}$} \\
\hline & & \multirow{2}{*}{$\begin{array}{c}\mathbf{0} \\
42.11 \pm 1.63 \\
\end{array}$} & \multirow{2}{*}{$\begin{array}{c}\mathbf{2} \\
40.22 \pm 3.13\end{array}$} & \multirow{2}{*}{$\frac{\mathbf{4}}{40.26 \pm 0.81^{b}}$} & \multirow{2}{*}{$\frac{\mathbf{8}}{38.13 \pm 2.76^{b}}$} \\
\hline & CTL 0\% & & & & \\
\hline \multirow[t]{3}{*}{$\mathbf{L}^{*}$} & SP 0.2\% & $46.52 \pm 3.86$ & $43.88 \pm 2.98$ & $45.53 \pm 2.60^{\mathrm{a}}$ & $45.22 \pm 2.27^{\mathrm{a}}$ \\
\hline & SC $0.4 \%$ & $45.70 \pm 2.82^{\mathrm{A}}$ & $40.56 \pm 1.70^{\mathrm{B}}$ & $38.21 \pm 1.62^{\mathrm{Bb}}$ & $38.33 \pm 1.86^{\mathrm{Bb}}$ \\
\hline & CTL 0\% & $14.14 \pm 2.01$ & $13.94 \pm 2.17$ & $14.05 \pm 1.12$ & $11.24 \pm 0.92^{\mathrm{b}}$ \\
\hline \multirow[t]{3}{*}{$a^{*}$} & SP 0.2\% & $15.47 \pm 2.50$ & $15.01 \pm 1.14$ & $14.68 \pm 0.70$ & $14.09 \pm 2.03^{\mathrm{a}}$ \\
\hline & SC $0.4 \%$ & $17.42 \pm 0.45^{\mathrm{A}}$ & $15.21 \pm 2.34^{\mathrm{AB}}$ & $14.58 \pm 1.24^{\mathrm{B}}$ & $13.41 \pm 0.53^{\mathrm{Bab}}$ \\
\hline & CTL 0\% & $21.36 \pm 2.41$ & $22.45 \pm 4.73$ & $22.92 \pm 1.98^{b}$ & $19.28 \pm 2.55^{\mathrm{b}}$ \\
\hline \multirow[t]{2}{*}{$\mathbf{b}^{*}$} & SP 0.2\% & $23.05 \pm 3.62$ & $24.39 \pm 2.14$ & $27.22 \pm 1.24^{\mathrm{a}}$ & $27.12 \pm 1.92^{\mathrm{a}}$ \\
\hline & SC $0.4 \%$ & $24.00 \pm 0.53$ & $23.90 \pm 2.25$ & $21.99 \pm 1.85^{\mathrm{b}}$ & $21.37 \pm 2.54^{\mathrm{b}}$ \\
\hline
\end{tabular}

${ }^{1)}$ Treatments are the same as in Table 2.

${ }^{\mathrm{a}, \mathrm{b}}$ Means \pm SD with different superscripts in the same column significantly differ at $\mathrm{p}<0.05$.

${ }^{\mathrm{A}, \mathrm{B}}$ Means \pm SD with different superscripts in the same row significantly differ at $\mathrm{p}<0.05$.

Table 6:-Changes in TBARS and VBN during cold storage

\begin{tabular}{|l|l|c|c|c|c|}
\hline \multirow{2}{*}{\multicolumn{2}{|c|}{ Treatments $^{\mathbf{2}}$}} & \multicolumn{4}{c|}{ Storage days } \\
\cline { 2 - 6 } & CTL 0\% & $0.98 \pm 0.18^{\mathrm{C}}$ & $2.78 \pm 0.19^{\mathrm{Ba}}$ & $2.59 \pm 0.10^{\mathrm{Ba}}$ & $3.75 \pm 0.07^{\mathrm{Aa}}$ \\
\hline \multirow{2}{*}{$\begin{array}{l}\text { TBARS } \\
(\mathbf{M A ~ m g / k g )})\end{array}$} & SP 0.2\% & $0.91 \pm 0.05^{\mathrm{D}}$ & $2.16 \pm 0.06^{\mathrm{Cb}}$ & $2.27 \pm 0.03^{\mathrm{Bb}}$ & $3.62 \pm 0.07^{\mathrm{Aa}}$ \\
\cline { 2 - 6 } & SC 0.4\% & $0.87 \pm 0.18^{\mathrm{C}}$ & $1.94 \pm 0.13^{\mathrm{Bb}}$ & $2.14 \pm 0.13^{\mathrm{Bb}}$ & $2.87 \pm 0.12^{\mathrm{Ab}}$ \\
\hline \multirow{2}{*}{$\begin{array}{l}\text { VBN } \\
(\mathbf{m g \%})\end{array}$} & CTL 0\% & $17.57 \pm 0.33^{\mathrm{Ba}}$ & $19.77 \pm 2.80^{\mathrm{ABa}}$ & $21.68 \pm 2.27^{\mathrm{A}}$ & $21.89 \pm 0.99^{\mathrm{A}}$ \\
\cline { 2 - 7 } & SP 0.2\% & $16.52 \pm 1.61^{\mathrm{Ba}}$ & $17.35 \pm 1.43^{\mathrm{ABab}}$ & $19.76 \pm 4.66^{\mathrm{AB}}$ & $22.38 \pm 0.69^{\mathrm{A}}$ \\
\cline { 2 - 7 } & SC 0.4\% & $13.95 \pm 0.16^{\mathrm{Cb}}$ & $15.08 \pm 1.20^{\mathrm{BCb}}$ & $17.71 \pm 3.33^{\mathrm{B}}$ & $21.17 \pm 0.48^{\mathrm{A}}$ \\
\hline
\end{tabular}

1) Treatments are the same as in Table 2.

${ }^{2)}$ Thiobarbituric acid reactive substance (malonaldehyde $\mathrm{mg} / \mathrm{kg}$ ).

${ }^{\mathrm{a}, \mathrm{b}}$ Means \pm SD with different superscripts in the same column significantly differ at $\mathrm{p}<0.05$.

A,B,C,D Means \pm SD with different superscripts in the same row significantly differ at $p<0.05$.

Table 7:-Changes in total bacterial counts during cold storage

\begin{tabular}{|l|c|c|c|c|}
\hline \multirow{2}{*}{ Treatments $^{\mathbf{1}}$} & \multicolumn{4}{|c|}{ Storage days } \\
\cline { 2 - 5 } & $\mathbf{0}$ & $\mathbf{2}$ & $\mathbf{4}$ & $\mathbf{8}$ \\
\hline CTL 0\% & $1.95 \pm 0.07^{\mathrm{C}}$ & $2.67 \pm 0.16^{\mathrm{B}}$ & $3.02 \pm 0.60^{\mathrm{AB}}$ & $3.39 \pm 0.10^{\mathrm{Aa}}$ \\
\hline SP 0.2\% & $2.30 \pm 0.43^{\mathrm{B}}$ & $2.89 \pm 0.06^{\mathrm{AB}}$ & $3.11 \pm 0.71^{\mathrm{AB}}$ & $3.46 \pm 0.16^{\mathrm{Aa}}$ \\
\hline SC 0.4\% & $1.74 \pm 0.37^{\mathrm{B}}$ & $2.60 \pm 0.68^{\mathrm{A}}$ & $2.98 \pm 0.14^{\mathrm{A}}$ & $3.01 \pm 0.27^{\mathrm{Ab}}$ \\
\hline
\end{tabular}

${ }^{1)}$ Treatments are the same as in Table 2.

${ }^{\mathrm{a}, \mathrm{b}}$ Means \pm SD with different superscripts in the same column significantly differ at $\mathrm{p}<0.05$.

${ }_{A, B, C}$ Means $\pm S D$ with different superscripts in the same row significantly differ at $\mathrm{p}<0.05$. 
Table 8:-Changes in sensory score during cold storage

\begin{tabular}{|c|c|c|c|c|c|}
\hline \multirow{2}{*}{ Items } & \multirow{2}{*}{ Treatments $^{2)}$} & \multicolumn{4}{|c|}{ Storage days } \\
\hline & & $\mathbf{0}$ & 2 & 4 & 8 \\
\hline \multirow[t]{3}{*}{ Color } & CTL 0\% & $7.50 \pm 0.55^{\mathrm{AB}}$ & $7.00 \pm 0.63^{B}$ & $8.00 \pm 0.89^{A}$ & $8.00 \pm 0.89^{\mathrm{A}}$ \\
\hline & SP $0.2 \%$ & $7.33 \pm 0.52^{\mathrm{AB}}$ & $7.17 \pm 0.41^{\mathrm{B}}$ & $7.83 \pm 0.41^{\mathrm{A}}$ & $7.83 \pm 0.41^{\mathrm{A}}$ \\
\hline & SC $0.4 \%$ & $6.83 \pm 0.75^{\mathrm{B}}$ & $6.67 \pm 0.52^{\mathrm{B}}$ & $8.00 \pm 0.63^{A}$ & $8.00 \pm 0.63^{A}$ \\
\hline \multirow[t]{3}{*}{ Aroma } & CTL 0\% & $8.50 \pm 0.55^{\mathrm{a}}$ & $8.17 \pm 0.41^{\mathrm{a}}$ & $8.00 \pm 0.63$ & $8.33 \pm 0.82$ \\
\hline & SP $0.2 \%$ & $7.00 \pm 0.63^{\mathrm{Bb}}$ & $6.83 \pm 0.41^{\mathrm{Bb}}$ & $7.83 \pm 0.75^{\mathrm{A}}$ & $8.00 \pm 0.63^{\mathrm{A}}$ \\
\hline & SC $0.4 \%$ & $7.50 \pm 0.55^{\mathrm{Ab}}$ & $6.83 \pm 0.41^{\mathrm{Bb}}$ & $7.83 \pm 0.75^{\mathrm{A}}$ & $7.83 \pm 0.41^{\mathrm{A}}$ \\
\hline \multirow[t]{3}{*}{ Flavor } & CTL 0\% & $7.67 \pm 0.52^{\mathrm{AB}}$ & $7.00 \pm 0.63^{B}$ & $8.00 \pm 0.63^{A}$ & $8.17 \pm 0.98^{\mathrm{A}}$ \\
\hline & SP $0.2 \%$ & $7.33 \pm 0.52^{\mathrm{AB}}$ & $7.00 \pm 0.63^{\mathrm{B}}$ & $8.00 \pm 0.63^{\mathrm{A}}$ & $8.00 \pm 0.63^{A}$ \\
\hline & SC $0.4 \%$ & $7.50 \pm 0.55^{\mathrm{AB}}$ & $7.00 \pm 0.63^{B}$ & $8.00 \pm 0.63^{A}$ & $8.00 \pm 0.63^{\mathrm{A}}$ \\
\hline \multirow[t]{3}{*}{ Tenderness } & CTL 0\% & $8.50 \pm 0.55^{\mathrm{a}}$ & $8.17 \pm 0.41^{\mathrm{a}}$ & $8.50 \pm 0.55$ & $8.67 \pm 0.52$ \\
\hline & SP $0.2 \%$ & $6.83 \pm 0.75^{\mathrm{Bb}}$ & $6.67 \pm 0.52^{\mathrm{Bb}}$ & $8.00 \pm 0.63^{\mathrm{A}}$ & $7.83 \pm 0.98^{\mathrm{A}}$ \\
\hline & SC $0.4 \%$ & $7.33 \pm 0.52^{\mathrm{BCb}}$ & $7.00 \pm 0.63^{\mathrm{cb}}$ & $8.17 \pm 0.75^{\mathrm{A}}$ & $8.00 \pm 0.63^{\mathrm{AB}}$ \\
\hline \multirow[t]{3}{*}{ Juiciness } & CTL 0\% & $7.50 \pm 0.55^{\mathrm{AB}}$ & $6.83 \pm 0.41^{\mathrm{B}}$ & $8.17 \pm 0.75^{\mathrm{A}}$ & $8.17 \pm 0.75^{\mathrm{A}}$ \\
\hline & SP $0.2 \%$ & $7.50 \pm 0.55^{\mathrm{AB}}$ & $6.83 \pm 0.41^{\mathrm{B}}$ & $8.00 \pm 0.63^{A}$ & $8.00 \pm 0.63^{A}$ \\
\hline & SC $0.4 \%$ & $7.00 \pm 0.63^{\mathrm{B}}$ & $7.00 \pm 0.63^{B}$ & $8.00 \pm 0.63^{A}$ & $8.00 \pm 0.63^{A}$ \\
\hline \multirow{3}{*}{$\begin{array}{l}\text { Overall } \\
\text { acceptability }\end{array}$} & CTL 0\% & $8.33 \pm 0.52^{\mathrm{a}}$ & $8.00 \pm 0.63^{\mathrm{a}}$ & $8.17 \pm 0.75$ & $8.33 \pm 0.52$ \\
\hline & SP 0.2\% & $7.17 \pm 0.41^{\mathrm{Bb}}$ & $7.33 \pm 0.52^{\mathrm{Bab}}$ & $7.83 \pm 0.41^{\mathrm{A}}$ & $8.00 \pm 0.00^{\mathrm{A}}$ \\
\hline & SC $0.4 \%$ & $7.00 \pm 0.63^{\mathrm{Bb}}$ & $7.00 \pm 0.63^{\mathrm{Bb}}$ & $8.00 \pm 0.63^{A}$ & $8.17 \pm 0.41^{\mathrm{A}}$ \\
\hline
\end{tabular}

${ }^{1)}$ Sensory scores were assessed on 9 point scale base on 1=extremely bad or slight, $9=$ =xtremely good or much.

${ }^{2)}$ Treatments are the same as in Table 2.

${ }^{\mathrm{a}, \mathrm{b}}$ Means \pm SD with different superscripts in the same column significantly differ at $\mathrm{p}<0.05$.

${ }^{A, B, C}$ Means $\pm S D$ with different superscripts in the same row significantly differ at $\mathrm{p}<0.05$.

\section{Results and Discussion:-}

\section{PH characteristics of functional seasoned meat:-}

Recently, larvae have become a subject of diverse research as future food resources (Ha, et al., 2018; Kim et al., 2017). Therefore, in this study, we evaluated stability during storage under low temperature by seasoned meats prepared with insect - derived food materials.

Table 2 shows the changes in $\mathrm{pH}$ during storage period of functional seasoned meat supplemented with silkworm powder and silkworm cordyceps. The change of $\mathrm{pH}$ was significantly increased in all the groups $(\mathrm{p}<0.05)$ at 4 day of storage compared to the initial storage. After that day, the control and the silkworm cordyceps groups were significantly decreased until the 8th day of storage $(\mathrm{p}<0.05)$. However, the silkworm powder group did not show any significant difference ( $>0.05)$. There was no significant difference between the control and silkworm powder groups at the early stage of storage and at the end of storage ( $>>0.05)$, whereas silkworm cordyceps group was significantly lower values than those of the other groups $(\mathrm{P}<0.05)$.

After 2 days of storage during 10 days, the $\mathrm{pH}$ of Kochujang sauce was higher than that of soy sauce seasoned meat (Choi and Lee, 2002). During 10 day storage of soy sauce seasoned meat, the $\mathrm{pH}$ was not changed until 8th day, but it was significantly lower at 10th day. The kochujang seasoned meat was significantly higher on the 6th day of storage, but decreased significantly thereafter. The high and low $\mathrm{pH}$ phenomena during storage period showed the same tendency in both this and the previous studies. When the seasoned ribs were stored for 15 days at $-1^{\circ} \mathrm{C}$ in an aerobic, vacuum, and gas replacement packaging, there was no difference according to packaging method (Kim, et al., 2002). After 30 days of storage at $0^{\circ} \mathrm{C}$, the $\mathrm{pH}$ change did not change significantly when compared with the initial stage of storage (Jin, et al., 2004). In general, $\mathrm{pH}$ is elevated by factors such as the reaction of protein and ionic substances in meat, decrease of electrolyte dissociation and ammonia production during fermentation (Deymer and Vandekerckhove, 1979). The changes in $\mathrm{pH}$ were determined by the accumulation of basic substances during fermentation, the action of Lactobacilli and the generation of $\mathrm{CO}_{2}$ gas or the accumulation of lactic acid and the added seasoning ingredients (Demeyer and Vanderkerckhove, 1979; Paneras and Bloukas, 1994; Pearson and Young, 1989). 
Salinity saccharinity, and shear force of functional seasoned meats:-

Table 3 shows the changes in salinity and saccharinity during storage period of functional seasoned meats containing silkworm powder and silkworm cordyceps. The salinity was in the range of $0.5 \sim 0.7 \%$ throughout storage period. The control group was increased according to storage period elapse ( $p>0.05$ ), but silkworm powder group was no observed by significant difference ( $p>0.05$ ). Since salt-added meat products maintain alkaline properties in the added salt, raise the isokinetic $\mathrm{pH}$ of the meat and increase the solubility of muscle proteins, they are generally kept by high pH (Barbut and Mittal, 1991). Saccharinity tended to increase with storage period (p $<0.05$ ), and the silkworm cordyceps group showed a slightly higher saccharinity value than those of the other groups $(\mathrm{p}<0.05)$.

Table 4 shows the changes in shear force values during storage of functional seasoned meats containing silkworm powder and silkworm cordyceps. As the chemical composition of the meat affects the structure of the meat, the composition is involved in determining the physical properties. These complicated factors determine texture of meat products and sensory characteristics. Texture measurement of the meat is one of the most important ways to evaluate meat quality, and organization of the meat is an important criterion to evaluate taste of meat by consumers. The shear force values of all the groups decreased significantly with storage period elaspe $(p<0.05)$. Even though the same raw material was selected, the higher shear force values of the treated groups immediately after production became necessary to further investigate whether the difference was due to the deviation of the raw material of the hind leg or the effect of silkworm-related substances.

The improvement of tenderness is related to aging post mortem of the meat, and mechanism of softening of meat during aging period has not yet been clarified. In general, $\mathrm{pH}$ and temperature post mortem affect tenderness $(\mathrm{Yu}$ and Lee, 1986), and meat is softened by decomposition of myofibrillar proteins mainly by intramuscular enzymes (Yates et al., 1983). The shear forces of the treated groups were significantly higher values than that of the control (p $<0.05$ ), but no significant difference in between the treated groups during the whole storage period ( $p>0.05)$.

\section{Meat color of functional seasoned meats:-}

Table 5 shows the changes in meat color during storage of functional seasoned meat containing silkworm powder and silkworm cordyceps. Changes in meat color depend on the presence and amount of oxygen, storage temperature, enzymatic activity in the tissue, microbial contamination, $\mathrm{pH}$, packaging method, light and pressure (Cornforth, 1994). Consumers decide to make purchases by meat color when they purchase meat (Fontes et al., 2004; Zhu and Brewer, 1998).

There was no significant difference in lightness $\left(\mathrm{L}^{*}\right)$ and redness $\left(\mathrm{a}^{*}\right)$ between the control and silkworm powder groups ( $p>0.05$ ). The late parts of storage in meat color of the silkworm cordyceps group were significantly lower values than those of the early stage of storage $(p<0.05)$. On the other hand, $b^{*}$ values indicating yellowness were not significantly different in all the groups $(p>0.05)$. $\mathrm{L}^{*}, \mathrm{a}^{*}$, and $\mathrm{b}^{*}$ values of silkworm powder group were significantly higher than those of other groups $(\mathrm{p}<0.05)$.

\section{Lipid peroxidation and protein spoilage of function seasoned meats:-}

Table 6 shows changes in TBARS (thiobarbituric acid reactive substances) and VBN (volatile basic nitrogen) during storage of silkworm powder and silkworm cordyceps groups. The degree of lipid oxidation increases according to the storage period elapses (Youn, et al, 2004). The TBARS value in this study was also significantly increased depending on the storage period elapses (Table 6, p <0.05). The treated groups showed lower values of TBARS than the control group. Especially, silkworm cordyceps group showed significantly lower $(\mathrm{p}<0.05)$ value than those of the other groups. Therefore, it is suggested that the group is effective in inhibiting lipid rancidity.

VBN increases according to storage period lapse in seasoned meat (Choi and Lee, 2002; Jin, et al., 2005). In this study, VBN value was also increased with storage period ( $\mathrm{p}<0.05$ ). The silkworm cordyceps group maintained a somewhat lower value compared to other groups. When the VBN value of raw meat is above $30 \mathrm{mg} \%$, it is judged to be corrupt, but sometimes meat products do not become corrupt even more (Jin, et al., 2005). In this study, VBN values of $23 \mathrm{mg} \%$ or less were maintained until 8th day of storage.

Total bacterial count and sensory evaluation of functional seasoned meats:-

Table 7 shows the changes in total bacterial counts during the storage period of functional seasoned meats containing silkworm powder and silkworm cordyceps groups. Total bacterial counts were significantly increased in 
all the groups with storage period ( $\mathrm{p}<0.05$ ). The silkworm powder group, which had high initial pollution level of $2.30 \log 10 \mathrm{CFU} / \mathrm{cm}^{2}$, increased to $3.46 \log 10 \mathrm{CFU} / \mathrm{cm}^{2}$ at the 8 th day of storage, which was the highest bacterial count in all the groups $(\mathrm{p}<0.05)$. When the total number of bacteria are over $7 \log 10 \mathrm{CFU} / \mathrm{cm}^{2}$, off-flavor occurs in the meat, and when the level is $8 \log 10 \mathrm{CFU} / \mathrm{cm}^{2}$, mucus is formed (Ingram and Dainty, 1971). In this study, it was below $3.40 \log 10 \mathrm{CFU} / \mathrm{cm}^{2}$ level by 8 th day of storage. The shelf life of cold storage-meat is determined by the number of initial microorganisms, storage period, storage temperature and packaging method (Newton and Rigg, 1979). Since it has lower total number of bacteria than the other treatments during the storage period, it is suggested that the silkworm cordyceps group has some antimicrobial activity.

Table 8 shows the sensory evaluation results of functional seasoned meats containing silkworm powder and silkworm cordyceps groups during storage. As the storage period elapsed, meat color, flavor and juiciness were significantly higher in all groups $(\mathrm{p}<0.05)$, but aroma and tenderness were significantly increased only in the treated groups $(\mathrm{p}<0.05)$. The aroma and tenderness in the treated groups were lower in the early stage of storage than in the control, and these effects affected overall acceptability and were significantly lower until 2 days of storage ( $p$ $<0.05$ ). Thereafter, there was no significant difference by influence on the enhancement of flavor due to aging ( $\mathrm{p}>$ $0.05)$. On 8 days of storage, overall acceptability was maintained at 8.00 or higher.

Taken all together, since silkworm powder and silkworm cordyceps can improve the quality of the seasoned meats during storage, it is suggested that these can be used as food materials for improving storage stability.

\section{Acknowledgments:-}

This work was supported by Priority Research Centers Program through the National Research Foundation of Korea (NRF) funded by the Ministry of Education (2009-0093813).

\section{References:-}

1. Barbut, S. and Mittal, G. S. 1991. Effect of heat processing delay on the stability of poultry meat emulsions containing 1.5 and $2.5 \%$ salt. Poultry Sci. 70, 2538.

2. Buege, J. A. and Aust, J. D. 1978. Microsomal lipid peroxidation. Methods Enzymol. 52, 302-309.

3. Choi, W. S. and Lee, K. T. 2002. Quality changes and shelf-life of seasoned pork with soy sauce or Kochujang during chilled storage. Korean J. Food Sci. Ani. Resour. 22 (3), 240-246.

4. Cornforth, D. P. 1994. Color: Its basis and importance. In: Quality Attributes and Their Measurement in Meat, Poultry and Fish Product. Pearson, A. M. and Dutson, T. R. (eds), Blackie Academic \& Professional, London, England, p. 39.

5. Demeyer, D. I. and Vanderkerckhove, P. 1979. Compounds determining pH in dry sausage. Meat Sci. 3, 161165.

6. Fontes, P. R., Gomide, L. A. M., Ramos, E. M., Stringheta, P. C. and Parreiras, J. F. M. 2004. Color evaluation of carbon monoxide treated porcine blood, Meat Sci. 68, 507-513.

7. Ha, Y. J., Noh, C. W., Bang, W. Y., Kim, S. W. and Gal, S. W. 2018. Study on antibacterial activity of bee venom. Int. J. Adv. Res. 6 (1), 229-235.

8. Hah, K. H., Joo, S. T., Park, G. B., Sung, N. J., Lyou, H. J., Park, K. H., Kim, I. S. and Jin, S. K. 2005. Changes in taste compounds of seasoned pork with Korean traditional sauces during aging. Korean J. Anim. Sci. Technol. 47 (5), 857-866.

9. Ingram, M. and Dainty, R. H. 1971. Changes caused by microbes in spoilaged of meats., J. Appl. Bact. 34 (1), 21-39.

10. Jeon, M. S., Sohn, K. H., Chae, S. H., Park, H. K. and Jeon, H. J. 2002. Color characteristics of Korean traditional soy sauces prepared under different processing conditions. J Korean Soc. Food Sci. Nutr. 31(1), 3238.

11. Jin, S. K., Kim, I. S., Hur, S. J., Lyou, H. J., Hah, K. H., Joo, S. T. and Lee, J. I. 2004. Physico-chemical changes of pork prepared by Korean traditional sauces during chilled aging. J. Anim. Sci. \& Technol. (Kor.). 46, 859-870.

12. Jin, S. K., Kim, I. S., Hur, S. J., Park, K. H., Lyou, H. J., Kim, I. J. and Hah, K.H. 2005. Effect of traditional seasoning on quality characteristics of low temperature aging pork. Journal of Animal Science and Technology 47 (6), 1041-1050. 
13. Jin, S. K., Kim, I. S., Hah, K. H., Hur, S. J., Lyou, H. J., Park, K. H. and Bae, D. S. 2005. Changes of qulities in aerobic packed ripening pork using a Korea traditional seasoning durig storage. J. Anim. Sci. \& Technol. (Kor) 47 (1), 73-82.

14. Kim, I. S., Jin, S. K., Kang, S. N., Hur, I. C. and Choi S. Y. 2009. Effect of Olive-Oil Prepared Tomato Powder (OPTP) and Refining Lycopene on the Physicochemical and Sensory Characteristics of Seasoned Raw Pork During Storage. Korean J. Food Sci. Ani. Resour. 29 (3), 334-339.

15. Kim, S. M., Cho, Y. S., Sung, S. K., Lee, I. G., Lee, S. H. and Kim, D. G. 2002. Developments of functional sausage using plant extracts from pine needle and green tea. Kor. J. Food Sci. Ani. Resour. 22, 20-29.

16. Kim, S. W., Lee, C. W., Kim, T. W., jeon, S. H., Noh, C. W., Bang, W. Y. and Kim, I. S. 2017. Antiinflammatory activity of Partially purified bioactive materials from Protaetia brevitarsis seulensis larvae. Int. J. Adv. Res, 5 (11), 296-299.

17. MaCarthy, T. L., Kerry, J. P., Kerry, J. F., Lynch, P. B. and Buckley, D. J. 2001. Assessment of the antioxidation potential of natural food and plant extracts in fresh and previously frozen pork patties. Meat Sci. 57, 177-184.

18. Minussi, R. C., Rossi, M., Bologna, L., Cordi, L., Rptilio, D., Pastore, G. M. and Duran, N. 2003. Phenolic compounds and total antioxidant potential of commercial wine. Food Chem. 82, 409-416.

19. Montesinos-Herroro, C., del Río, M. A., Pastor, C., Brunetti, O. and Palou, L. 2009. Evaluation of brief potassium sorbate dips to control postharvest Penicillium decay on major citrus species and cultivars. Postharvest Biol. Technol. 52, 117-125.

20. Moon, J. H., Ryu, H. S. and Lee, K. H. 1991. Effect of garlic on the digestion of beef protein during storage. J. Korean Soc. Food Sci. Nutr. 20, 447-454.

21. Namiki, M. 1990. Antioxidants/antimutagens in food. Cri. Rev. Food Sci. Nutr. 29, 273-300.

22. Newton, K. G. and Rigg, W. J. 1979. The effect of film permeability on the storage life and microbiology of vacuum-packed meat. J. Apple. Bact. 47, 433-441.

23. Oh, D. H. 1986. Studies on the quality of cured meat in the processing. PhD thesis, Chonbuk National University, Jeonju, Korea.

24. Paneras, E. D. and Bloukas, J. G. 1994. Vegetable oils replace pork backfat for low-fat frankfurters. J. Food Sci. 59, 725-732.

25. Pearson, A. M. and Young, R. B. 1989. Muscle and meat biochemistry. Academic Press., New York, USA. pp. 457-460.

26. Pearson D. 1968. Application of chemical methods for the assessments of beef quality. J. Sci. Food Agri. 19, 366-369.

27. SAS. 1999. SAS/STAT Software for PC. Release 6.11, SAS Institute, Cary, NC, USA.

28. Yang, M. R., No, G. R., Kang, S. N., Kim, S. W. and Kim, I. S. 2015. Effect on cryopreservation stability of kimchi duruchigi supplemented with Rubus coreanus Miquel Extract. Journal of Life Science 2015.25 (12), 1362-1369.

29. Yates, L. D., Dutson, T. R., Caldwell, J. and Carpenter, Z. L. 1983. Effect of temperature and pH on the postmortem degradation of myofibrillar proteins. Meat Sci. 9, 157-162.

30. Youn, D. H., Moon, Y. H. and Jung, I. C. 2007. Changes in quality of pork patty containing red wine cold storage. Korean J. Life Sci. 17, 91-96.

31. Youn, S. K., Choi, J. S., Park, S. M. and Ahn, D. H. 2004. Studies on the improvement of shelf-life and quality of vacuum-packaged seasoned pork meat by added chitosan during storage. J. Anim. Sci. \& Technol. (Kor) 46 (6), 1023-1030.

32. Yu, L. P. and Lee, Y. B. 1986. Effects of postmortem $\mathrm{pH}$ and temperature on bovine muscle structure and meat tenderness. J. Food Sci. 51, 774-780.

33. Zhu, L. G. and Brewer, M. S. 1998. Discoloration of fresh pork as related to muscle and display conditions. J. Food Sci. 63, 763-767. 